\title{
Survival after out-of-hospital cardiac arrest: Are age and gender pivotal for the outcome after resuscitation?
}

I.v. Auenmüller, M. Christ, W. Dierschke, S. Fessaras,T. von den Benken, H.-J. Trappe

Background: Survival after out-of-hospital cardiac arrest (OHCA) increases. Former studies reported on different survival rates and outcomes between men and women after OHCA and worse outcome of patients $>65$ years.

Purpose: This study aims to investigate if gender and age are crucial for the outcome after out-of-hospital cardiopulmonary resuscitation.

Methods: All patients (pts) who were admitted to our hospital after resuscitation following outof-hospital cardiac arrest over a period of five years were included in this retrospective study. The patient's survival 5 days after resuscitation and survival until hospital discharge defined the study endpoints. For statistical analysis, the mean, standard deviation, Student's t-test and Chi-square test were used (level of significance $\mathrm{P}<0.05$ ).

Results: In this 5 year period 170 pts were admitted to our hospital after OHCA. 102 pts $(60,0$ $\%$ ) were male, 68 pts $(40,0 \%)$ female. The average age was $68,7 \pm 14,4$ years (range 18,0 97,0 years). Most of the cardiac arrests were witnessed (123 [72,4 \%]), first responder CPR was performed in half of the cases $(87[51,2 \%])$. One third of the pts had a shockable rhythm (64 [37,6 \%]). In the majority of cases ROSC was achieved pre-clinically (138 [81,2\%]). 80 pts $(47,1 \%)$ survived the first 5 days after resuscitation and 60 pts $(35,3 \%)$ could be discharged alive. Pts who survived the first 5 days were statistically significantly younger $(65,3 \pm 14,1$ years) than pts who died within this period $(71,7 \pm 14,2$ years, $p=0,003)$. In comparison of pts who could be discharged alive and pts who died in hospital we found that the survivors were significantly younger $(63,10 \pm 14,62$ years vs. $(71,72 \pm 13,46$ years; $p<0,001)$. Choosing a cutoff value of 65 years, we found that pts who are younger than 65 years survived more frequently the first 5 days after resuscitation $(41(51,3 \%)$ vs. $23(25,6 \%), p=0,001)$ and also until hospital discharge $(34(56,7 \%)$ vs. $30(27,3 \%),<0,001)$ than the patients who were older than this. Survival rates did not differ between men and women, neither for 5 day survival nor for survival until hospital discharge (Tab. 1-2).

\begin{tabular}{|l|l|l|l|}
\hline & $\begin{array}{l}\text { Patient with } 5 \text { day } \\
\text { survival after } \\
\text { OHCA (n= } \\
80 \text { )Anzahl }\end{array}$ & $\begin{array}{l}\text { Patients who } \\
\text { did within the } \\
\text { first } 5 \text { days after } \\
\text { OHCA } n=90\end{array}$ & P-value \\
\hline age (years) & $65,3 \pm 14,1$ & $71,7 \pm 14,2$ & $\mathbf{0 , 0 0 3}$ \\
\hline age $<\mathbf{6 5}$ years & $41(51,3 \%)$ & $23(25,6 \%)$ & $\mathbf{0 , 0 0 1}$ \\
\hline $\begin{array}{l}\text { gender } \\
\text {-male } \\
\text {-female }\end{array}$ & $\begin{array}{l}50(62,5 \%) \\
\text { 30 (37,5\%) }\end{array}$ & $\begin{array}{l}52(57,8 \%) \\
38(42,2 \%)\end{array}$ & 0,530 \\
\hline
\end{tabular}

Tab.1: 5 day survival: comparison of age and gender

\begin{tabular}{|l|l|l|l|}
\hline & $\begin{array}{l}\text { Patient who could } \\
\text { be discharged } \\
\text { alive }(n=60)\end{array}$ & $\begin{array}{l}\text { Patients who } \\
\text { did in hospital } \\
n=110\end{array}$ & P-value \\
\hline age (years) & $63,10 \pm 14,62$ & $71,72 \pm 13,46$ & $<0,001$ \\
\hline age $<\mathbf{6 5}$ years & $34(56,7 \%)$ & $30(27,3 \%)$ & $<0,001$ \\
\hline $\begin{array}{l}\text { gender } \\
\text {-male } \\
\text {-female }\end{array}$ & $\begin{array}{l}41(68,3 \%) \\
19(31,7 \%)\end{array}$ & $\begin{array}{l}61(55,5 \%) \\
49(44,5 \%)\end{array}$ & 0,101 \\
\hline
\end{tabular}

Tab.2: Survival until hospital discharge: comparison of age and gender

Conclusion: Former studies reported on worse survival rates of women after OHCA. In contrast to this, survival after OHCA did not differ between men and women in our study population. Still, we found that survival rates were higher in younger patients so that age obviously is a crucial factor for the outcome after resuscitation.

Conflict of interest: None 